\title{
Deformation and Fracture Behavior of
} Sandwiched Copper Foam Brazed Joint Using Amorphous Copper-Tin-Nickel-Phosphorus Filler

\author{
Nur Amirah Mohd Zahri ${ }^{1}$, Farazila Yusof ${ }^{1,2 *}$, Irfan Anjum Badruddin ${ }^{3}$, \\ A. S. Md. Abdul Haseeb ${ }^{1,4}$, Nazatul Liana Sukiman ${ }^{1,4}$ and Sarfaraz Kamangar ${ }^{3}$
}

${ }^{1}$ Department of Mechanical Engineering, Faculty of Engineering, University Malaya, Kuala Lumpur, Malaysia, ${ }^{2}$ Advanced Manufacturing and Material Processing (AMMP Centre), University Malaya, Kuala Lumpur, Malaysia, ${ }^{3}$ Mechanical Engineering Department, College of Engineering King Khalid University, Abha, Saudi Arabia, ${ }^{4}$ Centre of Advanced Materials (CAM), University Malaya, Kuala Lumpur, Malaysia

OPEN ACCESS

Edited by:

Guang Zeng,

Central South University, China

Reviewed by:

Sudagar $\mathrm{J}$

VIT-AP University, India

Chun Li,

Harbin Institute of Technology, China

*Correspondence:

Farazila Yusof farazila@um.edu.my

Specialty section:

This article was submitted to Environmental Materials,

a section of the journal

Frontiers in Materials

Received: 07 February 2021 Accepted: 04 May 2021

Published: 31 May 2021

Citation:

Mohd Zahri NA, YusofF, Badruddin IA, Haseeb ASMA, Sukiman NL and Kamangar S (2021) Deformation and Fracture Behavior of Sandwiched Copper Foam Brazed Joint Using Amorphous

Copper-Tin-Nickel-Phosphorus Filler.

Front. Mater. 8:665219.

doi: 10.3389/fmats.2021.665219
Utilization of open-cell metal foams in functional applications such as in energy absorption, noise absorber, heat insulator, and lightweight panels is trending in many industrial applications. The development of reliable joining technologies for sandwiched metal foams is crucial for thermal application and one of the techniques used is brazing process. In the current work, copper foam was sandwiched between a copper plate using amorphous filler of Cu-9.7Sn-5.7Ni-7.0P (Cu: copper, Sn: tin, Ni: nickel, and P: phosphorus) via brazing technique. The shear test was conducted on the brazed joint interface of copper/copper foam, while the compressive test was carried out on the brazed sample. Microstructures of the copper substrate surface obtained from the shear fracture of brazed copper/copper foam show the tear region and cleavage fractures. The stress-strain curve of shear and compressive strength explains the deformation behavior of the brazed sample.

Keywords: metal foam, porous, brazing, deformation, compressive, shear, stress-strain, fracture behavior

\section{INTRODUCTION}

Naturally porous materials such as corals, woods, and bones are lightweight and durable structures. These examples from nature have become an inspiration for metallurgist to produce porous metal foam structures (Zhao et al., 2006). Their use has started in the 1960s in the application of metallic foam for the cooling of inter-ballistic missile components of the US Navy. The commercial usage of metallic foams was available in the early 1980s and has wide applications such as in transportation, infrastructure and construction, automotive, aerospace, and military equipment (Nawaz et al., 2012; Liu et al., 2014). Research and development in metallic foam includes utilization in thermal applications, such as in heat exchanger equipment (Abadi et al., 2016), heat sinks in electronics (Hu et al., 2016), engine combustion, aircraft, and automotive systems (Shirzadi et al., 2008). There is a growing demand in metal foam, with a USD 82.0 million share in the global market (Grand View Research, 2017).

The fabrication process plays a vital role in the manufacturing of metal foam, in particular in the metal foam pore density (pore per inch: PPI) and porosity (\%). These properties determine the mechanical and thermal properties of metal foam, which affect its functionality in the intended application (Vesenjak et al., 2016). There are several methods of metal foam fabrication, such as 
electrodeposition (Kim et al., 2016), powder metallurgy, casting, metal vapor, and metal ions (Xie and Evans, 2004; Ramos and Dunand, 2012; Wang and Guo, 2016). The choice of process would depend on the required foam structure, whether open cell or closed cell. In addition, the metal foam material is selected based on their intended applications. Metal foam material can be fabricated from nickel (Ni) (Ochiai et al., 2010; Sun et al., 2018), iron (Fe) (Alavi et al., 2017), copper (Cu) (Rybar et al., 2016), aluminum (Al) (Saw et al., 2017), or stainless steel (SS) (Tuzovskaya et al., 2012).

The high surface area of metal foam enables the transfer of high amount of heat with a small volume of metal (Zhao, 2012). The foam structure consists of highly interconnected branches and porosities, which can be closed-cell or open-cell structures. Closed-cell metal foam generally has air-filled pores with cell wall barriers. In contrast, open-cell metal foam has continuous interconnected branches network formed a cell wall with a node. The interconnected branches of foams are surrounded by void spaces which are linked through pores (Tan and Chong, 2016). These voids create a highly porous structure and result in a large ratio of area per unit volume. Closed-cell metal foams are utilized in structural applications due to their strengths, while open-cell metal foams are applied in functional applications such as in cooling, heating, and condensing (Ghosh, 2009). Other applications of open-cell structures are in sound absorption and high temperature gas and fluid filtrations. Previous studies carried out a mechanical analysis of metal foam to identify the metal foam failure and behavior mechanisms. Chen et al. (2017) have studied the compression characteristics of open-cell $\mathrm{Cu}$ foam by varying the strain rates $\left(10^{-2}, 10^{-3}\right.$, and $\left.10^{-4} \mathrm{~s}^{-1}\right)$ and $\mathrm{Cu}$ foam porosity $(90.3,95.7$, and 96.4\%). The results show that the compression strengths, Young's modulus, and yield strength of the $\mathrm{Cu}$ foam, increase with increasing strain rate and decreasing $\mathrm{Cu}$ foam porosity. The failure mechanism of the compression deformation shows that the $\mathrm{Cu}$ foam experiences layer-by-layer collapse. This failure occurs due to the formation of stress concentration at the weak branch of $\mathrm{Cu}$ foam, as shown by the plastic stage deformation on the compressive stress-strain curve. Liu et al. (2014) have investigated the effect of strain rates ranging from $10^{-3}$ to $2,400 \mathrm{~s}^{-1}$ on the $\mathrm{Cu}$ foam mechanism and behavior. The compressive stress-strain curves of lotus-type porous $\mathrm{Cu}$ consist of a linear elastic stage, a plateau stage, and the densification stage for all strain rates. Material with a lower strain rate has less sensitivity toward stress-strain curve until the strain rate exceeds $1.0 \mathrm{~s}^{-1}$. The plateau stage of the compressive stress-strain curve would be affected by the high strain rate. At high strain rates, the gases in the pores have insufficient time to escape which directly increase the atmospheric pressure and lead to an increase in the plateau stress.

The current work has considered metal foam heat exchanger applications due to abundant of works on the thermal performance using a metal foam (Chein et al., 2009; Odabaee and Hooman, 2012; Hu et al., 2016; Zhang et al., 2018). In heat exchanger application, the fluid medium would pass through the pores and make contacts with the large surface area of metal foam branches (Kim et al., 2016). The flows of fluid medium through the metal foam pores require a high strength of foam branches and brazing joint. Several works have discussed the use of brazing in the fabrication of $\mathrm{Cu}$ foam heat exchangers (Chein et al., 2009; Ribeiro et al., 2012; Hu et al., 2016), although the process on joining of the metal foam heat exchanger was not explained in detail. But there are some of the researchers reported solely in metal foam joining without the application. Jarvis et al. (2011) have conducted the brazing of nickel (Ni) foam to Ti6Al4V (Ti: titanium, Al: aluminum, and $\mathrm{V}$ : vanadium) using $\mathrm{Ti} 15 \mathrm{Cu} 25 \mathrm{Ni}$ with different binder systems of polyvinyl alcohol (PVA), polyvinyl butyral (PVB), and polyethylene glycol-polymethyl methacrylate (PEGPMMA). Shear test results of the joints show that crack deformations were formed in a majority of the $\mathrm{Ni}$ foam area for joints produced with PVA and PVB binders, while the joint produced with PEG-PMMA binder has shown a line crack deformation on the $\mathrm{Ni}$ foam. These results suggest that joint failures tend to occur through the foam instead of in the joint interface. Nannan et al. (2013) have carried out brazing of aluminum (Al) foam-Al foam using Al86SiMg filler by varying the vacuum pressure $\left(6.63 \times 10^{-3}\right.$ and $\left.5.0 \mathrm{~Pa}\right)$ and the amount of filler layer (monolayer and multilayer). The joint bending strength of brazed Al foam-Al foam was the highest for the multilayer filler in high vacuum, followed by the joint produced with multilayer layer in a low vacuum and then with monolayer filler in high vacuum. Song et al. (2015) have fabricated a steel/aluminum foam/steel sandwiched brazed joint using an aluminum-silicon-based alloy filler. It was found that increasing the brazing time for an additional $10 \mathrm{~min}$ resulted in the decrease of the shear joint strength due to formation of a brittle phase. The highest shear strength obtained was $6.26 \mathrm{MPa}$ for the joint produced at $620^{\circ} \mathrm{C}$ for 10 min brazing time. Ubertalli et al. (2017) have studied the joining of AA6016 (Al0.25Mg1.0Si)/Al foam/AA6016 using different fillers of $\mathrm{Zn}(250 \mu \mathrm{m}$ thickness $)$ and $\mathrm{Zn}+2 \% \mathrm{Al}$ $\left(350 \mu \mathrm{m}\right.$ thickness) with $5 \mathrm{~min}$ holding time at $430^{\circ} \mathrm{C}$ and $1 \mathrm{~min}$ holding time at $420^{\circ} \mathrm{C}$, respectively. The joining using $\mathrm{Zn}+2 \% \mathrm{Al}$ filler shows higher stiffness with the diffusion of Al-rich and Zn-rich in the joining area. Zahri et al. (2019) found the strength of brazed $\mathrm{Cu}$ foam with a $\mathrm{Cu}-4.0 \mathrm{Sn}-9.9 \mathrm{Ni}$ $7.8 \mathrm{P}$ amorphous filler is dependent on the foam pore density. The diffusion of $\mathrm{P}$ and $\mathrm{Ni}$ elements into the foam allows it to coat the foam branches and leads to the increase in foam strength. Similar phenomenon was found by Sami et al. (2020). Authors investigated the sandwiched $\mathrm{Cu}$ foam brazing using a single layer of $\mathrm{Cu}-9.7 \mathrm{Sn}-5.7 \mathrm{Ni}-7 \mathrm{P}$ foil at $680^{\circ} \mathrm{C}$ for $15 \mathrm{~min}$. Phosphorus plays a vital role in hardening foam branches which higher phosphorus percentage was found across the foam. Besides, the nickel percentage also was discovered higher in the middle and the top-side joint of the foam. Studies on metal foam joining have been increasing in recent years. However, research on the deformation behavior of metal foam is still scarce. Hence, the aims of this study are to investigate the deformation behavior through a 1) compressive strength of $\mathrm{Cu} / \mathrm{Cu}$ foam $/ \mathrm{Cu}$ which will accommodate a strong mass fluid flow during heat exchanger operation and 2) shear strength of $\mathrm{Cu} / \mathrm{Cu}$ foam 
joining which may affect the thermal conduction due to the thermal resistance at the joining interface (Heo et al., 2019).

\section{MATERIALS AND METHODS}

The $\mathrm{Cu}$ foam of different pore densities $15 \mathrm{PPI}, 25 \mathrm{PPI}$, and 50 PPI (hereinafter referred to as foam A, foam B, and foam C, respectively) was purchased from Duranice Applied Materials (Dalian, China). The pore densities (ranging from 15 PPI to 50 $\mathrm{PPI}$ ) of $\mathrm{Cu}$ foam were chosen due to their influence in heat rate performance. Mancin et al. (2012) have found that very high pore density (60 PPI and above) in foam metal would cause a pressure drop in the heat exchanger and require more pumping power. The foam was sandwiched between $\mathrm{Cu}$ (C \& W hardware, Kuala Lumpur, Malaysia) with amorphous $\mathrm{Cu}-9.7 \mathrm{Sn}-5.7 \mathrm{Ni}-7.0 \mathrm{P}$ filler (Metglas ${ }^{\circledR}$ Inc., Conway, United States) was in between faying surface of $\mathrm{Cu}$ and $\mathrm{Cu}$ foam.

The sample of $\mathrm{Cu} /$ filler/Cu foam/filler/Cu was undergone a brazing process at difference brazing temperatures (660C, 680C, $700 \mathrm{C}$, and $720^{\circ} \mathrm{C}$ ). Four different brazing temperature parameters were fixed above the filler liquidus temperature of $643^{\circ} \mathrm{C}$ (Zahri et al., 2020). The argon gas was used to avoid oxidation during brazing at a high temperature. The formation of oxide on the specimen's surface would reduce the wettability of the filler, resulting in a weak joint. The short holding time of $5 \mathrm{~min}$ was selected to minimize the energy used (Zhong et al., 2012) without jeopardizing the mechanical strength of the joint. The brazing cycle consisted of a preheating stage at $350^{\circ} \mathrm{C}$ for $30 \mathrm{~min}$. Zaharinie et al. 2015 have reported that a preheating stage of $350^{\circ} \mathrm{C}$ for $30 \mathrm{~min}$ would not affect the grain growth as the preheating temperature was less than the targeted annealing temperature range. The preheating may soften and assist in the full melting of the filler metal during brazing. The uniform heating rate and preheating phases were fixed at $5^{\circ} \mathrm{C} / \mathrm{min}$ and $30 \mathrm{~min}$, respectively, because $\mathrm{Cu}$ is usually difficult to join rapidly due to its high thermal conductivity (Srinath et al., 2011). Finally, the specimen was cooled at a slow rate of $5^{\circ} \mathrm{C} / \mathrm{min}$ to avoid formation of residual stresses and allow the intermetallic compound phases to achieve a stable equilibrium (Ubertalli et al., 2017).

The Image $1.52 \mathrm{v}$ (Wayne Rasband, National Institutes of Health, United States) was used to measure the size of $\mathrm{Cu}$ foam structure. The compression test and the shear test were performed to evaluate the brazed joint strength of $\mathrm{Cu} / \mathrm{Cu}$ foam and compressive strength of brazed $\mathrm{Cu} / \mathrm{Cu}$ foam $/ \mathrm{Cu}$ foam, respectively. It was conducted in accordance to ASTM Standard C273 for sandwich core materials using an Instron Universal Testing Machine 3369 equipped with Bluehill 2.0 software (Instron Inc., Norwood, United States). A $50 \mathrm{kN}$ load cell was fitted operating in displacement control mode at a crosshead speed of $1 \mathrm{~mm} / \mathrm{min}$, conducted at room temperature. Then, the fractured $\mathrm{Cu}$ substrate surface from $\mathrm{Cu} / \mathrm{Cu}$ foam shear fracture, in this shear test, was analyzed for fracture behavior. Scanning electron microscope (SEM) micrographs of the fractured $\mathrm{Cu}$ substrate surface were acquired using a JEOL JSM 6360A (Tokyo, Japan). In addition, energy-dispersive
X-ray spectroscopy (EDX) analysis was carried out to obtain elemental composition (\%) of the samples. The EDX apparatus was equipped with the elemental analysis software JEOL JED2300 (Tokyo, Japan).

\section{RESULTS}

\section{Cu Foam}

Figure 1 shows a macroscopic $\mathrm{Cu}$ foam with different pore densities for a $\mathrm{Cu} / \mathrm{Cu}$ foam brazing. The size of $\mathrm{Cu}$ foam structure, including cell wall area, pore diameter area, and branch area, was measured using ImageJ software as tabulated in Table 1. Macroscopic images and measurements show the decrease in sizes of the pores, cell walls, and $\mathrm{Cu}$ foam branches from foam $\mathrm{A}$, foam $\mathrm{B}$, and foam $\mathrm{C}$, respectively. However, the number of $\mathrm{Cu}$ foam interconnected branches had increased from foam A to foam B and finally to foam C, increasing the surface area of the foam. It has been reported that the increase in $\mathrm{Cu}$ foam pore density would result in the increase in total heat transfer and pressure drop. Hu et al. (2016) have reported that the increase in $\mathrm{Cu}$ foam from 5 PPI to 15 PPI yields total heat transfer rate and pressure drop increment by 67 and $62 \%$, respectively.

\section{Compressive Strength of $\mathrm{Cu} / \mathrm{Cu}$ Foam/Cu}

Figure 2 shows a constant compressive strength value of $\mathrm{Cu} / \mathrm{Cu}$ foam $/ \mathrm{Cu}$ as the brazing temperature increases from $660 \mathrm{C}$ to $700^{\circ} \mathrm{C}$, followed by an increase at $720^{\circ} \mathrm{C}$. The brazing temperature parameter was fixed up to $720^{\circ} \mathrm{C}$ only regardless of highest compressive strength value. This is due to the high value of compressive strength, $\mathrm{Cu}$ foam branches degradation, and required strength in application utilization. Further elaboration is explained in discussion section. Next, the pore density of $\mathrm{Cu}$ foam has a significant effect on the compressive strength performance. The compressive strengths of $\mathrm{Cu} / \mathrm{Cu}$ foam/ $\mathrm{Cu}$ increase from foam $\mathrm{A}$ to foam $\mathrm{B}$ and finally to foam $\mathrm{C}$ as shown in Figure 2. In comparison, the compressive strengths of nonbrazed $\mathrm{Cu} / \mathrm{Cu}$ foam/ $\mathrm{Cu}$ for foam $\mathrm{A}$, foam $\mathrm{B}$, and foam $\mathrm{C}$ were 3.23, 5.31, and 7.74 MPa, respectively, as shown as a straight line in Figure 2. The compressive strength of nonbrazed samples was lower than the values obtained for brazed sample. The percentage increments between nonbrazed and the highest compressive strength of brazed sample (at $720^{\circ} \mathrm{C}$ ) were 102.34 , 69.77 , and $43.16 \%$ for foam $\mathrm{A}$, foam $\mathrm{B}$, and foam $\mathrm{C}$, respectively.

Next, the compressive stress-strain curve of brazed $\mathrm{Cu} / \mathrm{Cu}$ foam/Cu using amorphous filler at brazing temperature of $720^{\circ} \mathrm{C}$ was plotted in Figure 3. Generally, a compressive stress-strain curve of porous materials can be divided into three regions which are linear elastic, plateau, and densification (Gnyloskurenko et al., 2005; Liu et al., 2014; Haidar and Sekh, 2018).

\section{Shear Strength of Cu/Cu Foam Brazed Joint Interface}

The shear strengths of $\mathrm{Cu} / \mathrm{Cu}$ foam using amorphous filler increase as the brazing temperature increases from 660 to $680^{\circ} \mathrm{C}$ as shown in Figure 4. A decrease in shear strength was 

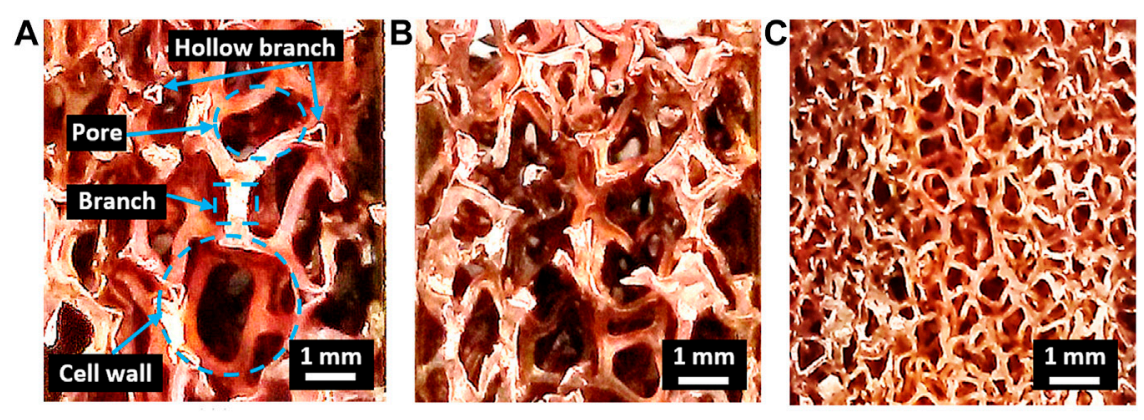

FIGURE 1 | Cu foam macrostructure (A) foam A, (B) foam b, and (C) foam C.

TABLE 1 | Size of Cu foam for (A) foam A, (B) foam B, and (C) foam C

Cu foam

Cell wall area $\left(\mathrm{mm}^{2}\right)$

Pore area $\left(\mathrm{mm}^{2}\right)$

Inner section of branch area $\left(\mu \mathrm{m}^{2}\right)$

Foam A (15 PPI)

Foam B (25 PPI)

$6.39 \pm 0.22$

$3.04 \pm 0.40$

$1.06 \pm 0.23$

$41.3 \pm 3.2$

Foam C (50 PPI)

$1.00 \pm 0.40$

$0.50 \pm 0.09$

$24.7 \pm 3.5$

$0.13 \pm 0.01$

$6.6 \pm 1.2$

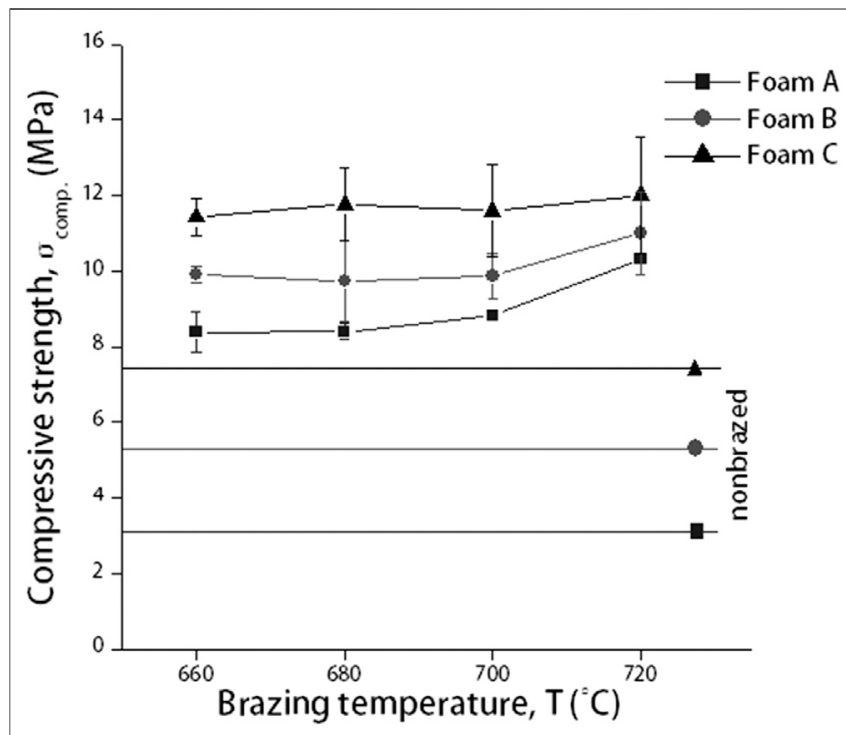

FIGURE 2 | Compressive strength of nonbrazed and brazed Cu/Cu foam/Cu using amorphous filler with different $\mathrm{Cu}$ foam pore densities and brazing temperature.

seen as the brazing temperature increases to $700^{\circ} \mathrm{C}$ with an insignificant increase as the brazing temperature reaches $720^{\circ} \mathrm{C}$. The parameter of brazing temperature was not further investigated beyond $720{ }^{\circ} \mathrm{C}$ due to insignificant increasing shear strength from brazing temperature at $700-720^{\circ} \mathrm{C}$. Beside the highest shear strength obtained for $\mathrm{Cu} / \mathrm{Cu}$ foam using amorphous filler is at a brazing temperature of $680^{\circ} \mathrm{C}$ for all $\mathrm{Cu}$ foam pore densities. While increasing the $\mathrm{Cu}$ foam, density was found to have reduced the shear strengths of the joint. Foam

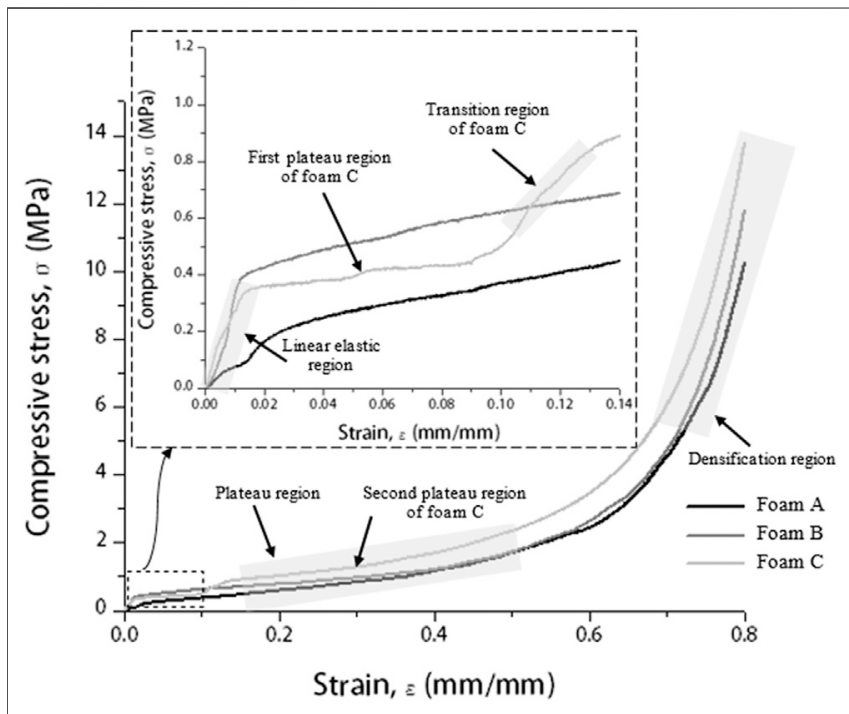

FIGURE 3 | Compressive stress-strain curve of brazed Cu/Cu foam/Cu at a brazing temperature of $720^{\circ} \mathrm{C}$ with different $\mathrm{Cu}$ foam pore densities and inset shows an elastic curve at a strain range of $0-0.14 \varepsilon$.

$\mathrm{C}$ has a higher porosity and smaller pore sizes as compared to foam A but has lower shear strength.

Figure 5 shows shear stress-strain curves of brazed $\mathrm{Cu} / \mathrm{Cu}$ foam/ $\mathrm{Cu}$ using amorphous filler with different $\mathrm{Cu}$ foam pore densities at $680^{\circ} \mathrm{C}$ brazing temperature. The brazing temperature was selected based on the highest shear strength (Figure 4). Generally, a shear stress-strain curve of $\mathrm{Cu} / \mathrm{Cu}$ foam brazed joint can be divided into four regions which are elastic, plateau, densification, and shearing (Kaya, 2020). 


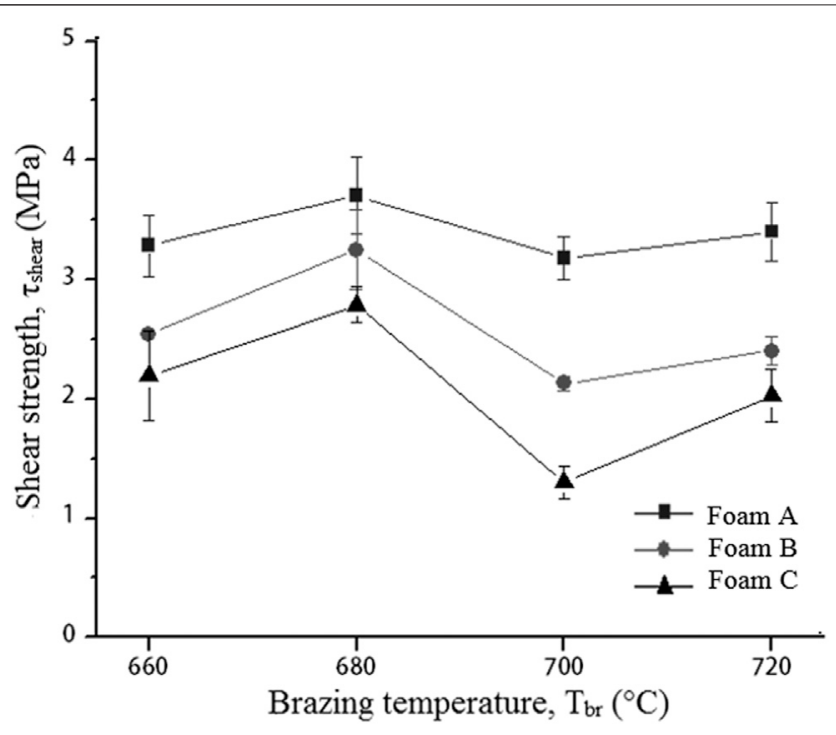

FIGURE 4 | Shear strength of brazed Cu/Cu foam using amorphous filler with different $\mathrm{Cu}$ foam pore densities and brazing temperature.

\section{Shear Fracture of Cu Substrate Surface From Brazed Cu/Cu Foam}

Figure 6 shows top view back scattered electron (BSE) image of $\mathrm{Cu}$ substrate shear fracture surface from the brazed $\mathrm{Cu} / \mathrm{Cu}$ foam shear test. From the images, it can be deduced that the shear fracture of brazed $\mathrm{Cu} / \mathrm{Cu}$ foam experienced a mixture of ductile and brittle fracture. The tear region shows high concentration of $\mathrm{Cu}$ and phosphorus (P), indicating a brazed joint interface between $\mathrm{Cu}$ and $\mathrm{Cu}$ foam branches.

Side-view BSE images of $\mathrm{Cu}$ substrate surface from the $\mathrm{Cu} / \mathrm{Cu}$ foam shear fracture were also captured as shown in Figure 7. The dark gray (island-shaped) and light gray areas indicating the filler and the diffusion regions, respectively. The diffusion region, shown as a brighter area than the $\mathrm{Cu}$ substrate, is an interaction layer between $\mathrm{Cu} /$ filler and $\mathrm{Cu}$ foam/filler which are formed during brazing.

\section{DISCUSSION}

The constant compressive strength of $\mathrm{Cu} / \mathrm{Cu}$ foam $/ \mathrm{Cu}$ from 660 to $700^{\circ} \mathrm{C}$ could be due to the inability of filler $\mathrm{B}$ to flow to the $\mathrm{Cu}$ foam via capillary action. Increasing the brazing temperature enabled sufficient heat input to provide the required energy to break the atomic bonds in the amorphous filler, allowing it to flow freely and coat the $\mathrm{Cu}$ foam branch. This has resulted in the increase in compressive strengths at $720^{\circ} \mathrm{C}$. The highest compressive strength of foam $\mathrm{C}$ can be attributed to the abundance of branching structure as shown in Figure 1C. The increase in compressive strengths with the increase in $\mathrm{Cu}$ foam pore densities correlate to the rise in the size of $\mathrm{Cu}$ foam structure, as tabulated in Table 1. Figure 1 shows the high number of branches in foam $\mathrm{C}$ as compared to foam $\mathrm{B}$ and foam $\mathrm{A}$. This interconnected branch would be able to resist the applied load better than foams with lesser interconnected branches. The increase in the amounts of $\mathrm{Cu}$ foam branches in foam $\mathrm{A}$, foam $\mathrm{B}$, and foam $\mathrm{C}$ would correspondingly increase their compressive strength values. In comparison, the result presents that by using amorphous filler in the brazed $\mathrm{Cu}$ / $\mathrm{Cu}$ foam/ $\mathrm{Cu}$ would significantly enhance its compressive strength performance. During brazing, the molten filler flows toward the $\mathrm{Cu}$ foam branches and would coat them during solidification. The solidified filler on the $\mathrm{Cu}$ foam branches would increase the compressive strength of the brazed $\mathrm{Cu} / \mathrm{Cu}$ foam $/ \mathrm{Cu}$ as compared to the nonbrazed $\mathrm{Cu} /$ $\mathrm{Cu}$ foam $/ \mathrm{Cu}$.

The compressive stress-strain curve of brazed $\mathrm{Cu} / \mathrm{Cu}$ foam $/ \mathrm{Cu}$ shows that in the linear elastic region (inset of Figure 3), the stress gradually increases with increasing strain, at a low strain range $(<0.015)$. Here, the compressive stress concentration reaches the yield strength of the $\mathrm{Cu}$ foam cell wall and leads to a reduction of $\mathrm{Cu}$ foam pore size. Beyond the elastic region, the plastic deformation of the $\mathrm{Cu} / \mathrm{Cu}$ foam $/ \mathrm{Cu}$ is indicated by a plateau region. A long and smooth plateau region corresponds to a ductile behavior with nearly constant stress. It can be theorized from this result that $\mathrm{Cu} / \mathrm{Cu}$ foam/Cu can still absorb the energy of the impact even though it was in a state of compressive deformation. The compressive stress-strain curve also illustrates the ability of foam $\mathrm{C}$ to absorb excess energy because of its high-stress amplitude. The continual deformation causes the reduction in pore size and porosities of $\mathrm{Cu}$ foam (Liu et al., 2010). Finally, a sharp increase in densification with increasing strain indicates compaction on the $\mathrm{Cu}$ foam branches. When the $\mathrm{Cu}$ foam becomes sufficiently compact, the cell wall would collapse with further load application. The compressive stress-strain curve of brazed $\mathrm{Cu} / \mathrm{Cu}$ foam $/ \mathrm{Cu}$ with a foam $\mathrm{C}$ shows a primary (first) and secondary plateau regions. The first and secondary plateau regions appear in the stress-strain curve due to the deformation of foam $\mathrm{C}$ is considered to occur in the high porosity layer and then shifted to the low porosity layer, respectively. Initially, the deformations started in the high porosity layer present primary maximum stress in the first plateau region. The continual deformation causes the reduction in foam porosity, and pore size leads to the initial point of densification for the high porosity layer. However, at this point, it is considered as the endpoint of the first plateau region because the second plateau region appeared indicates the deformation of the low porosity layer. At this stage, the deformation of $\mathrm{Cu}$ foam shifted to the low porosity layer, which is known as the transition region. The transition step for a deformation of $\mathrm{Cu}$ foam low porosity layer occurs due to the $\mathrm{Cu}$ foam high porosity layer has been collapsed in the early stage. After that, the densification of the $\mathrm{Cu}$ foam low porosity layer started. The stress increase sharply in the densification region indicates the $\mathrm{Cu}$ foam branches become sufficiently collapse and compact. Hangai et al. (2015) have reported similar plateau regions in the compressive stress-strain curve for the deformation behavior study of functionally graded aluminum foams. Authors improved the aluminum foam by adding a blowing agent titanium (II) 


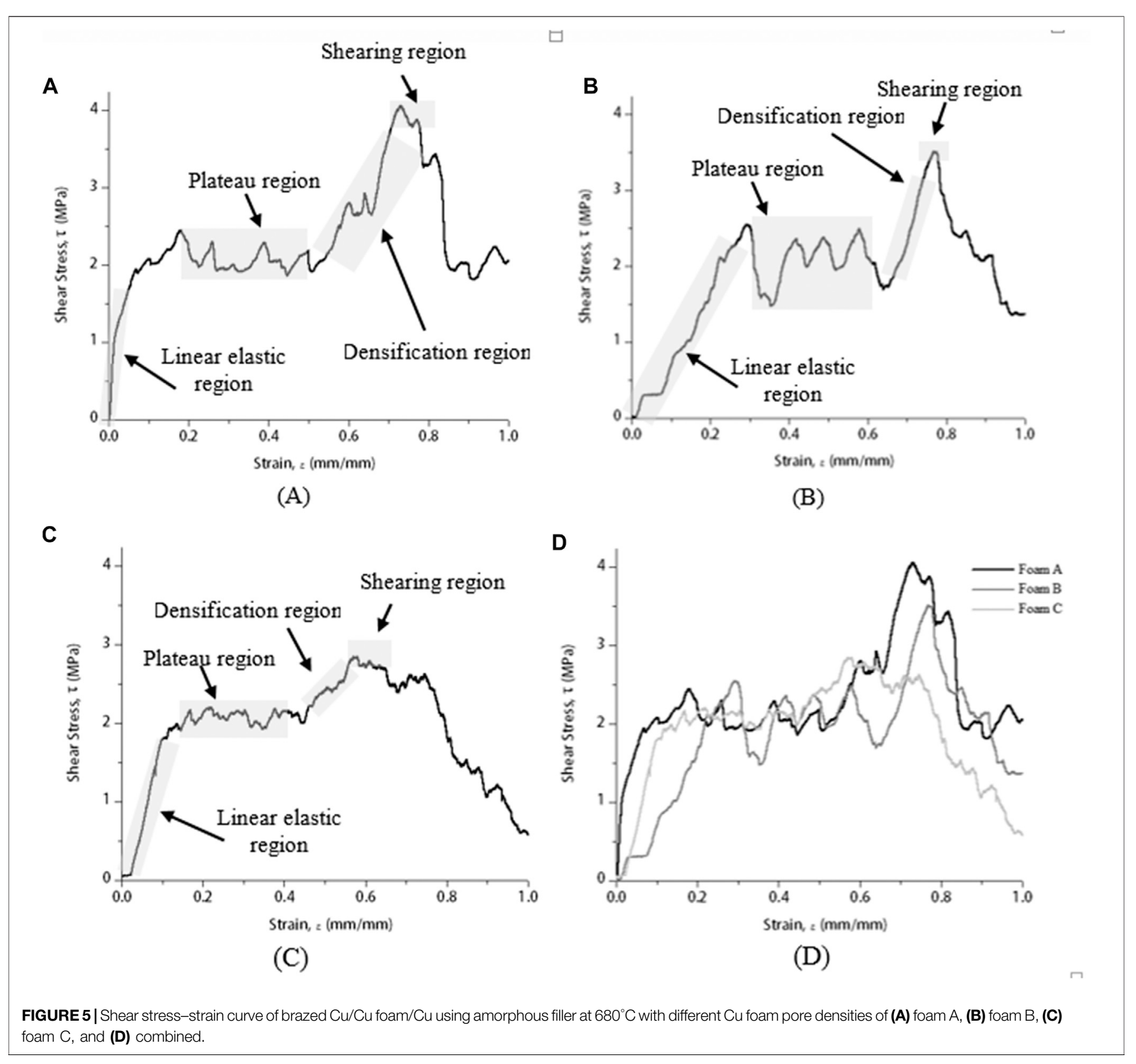

hydride $\left(\mathrm{TiH}_{2}\right)$ using a friction stir welding method. The result shows different steps in the plateau region in the compressive stress-strain curve with the addition of $\mathrm{TiH}_{2}$. Authors found that the combination of high porosity and low porosity layers of foam can control the foam deformation.

On the other hand, the highest shear strength of $\mathrm{Cu} / \mathrm{Cu}$ foam is at brazing temperature of $680^{\circ} \mathrm{C}$. The heat is considered sufficient for the diffusion of filler atoms into the brazed joint interface of $\mathrm{Cu} / \mathrm{Cu}$ foam. However, further increasing the brazing temperature would compromise the strength of $\mathrm{Cu}$ foam due to the fragility of its interconnected branches. A high brazing temperature would cause coarseness in the microstructure formation and decrease the shear strength of $\mathrm{Cu} / \mathrm{Cu}$ foam. The interconnected structure with small branches (foam C) resulted in a large surface area between $\mathrm{Cu}$ and $\mathrm{Cu}$ foam $\mathrm{C}$ (Figure 1). However, this large surface area did not result in increased shear strength properties as the molten filler has to spread in more hollow spaces in foam C. This observation is similar to past results which have found that a highly porous metal yields low shear strengths. For example, Wan et al. (2012) have conducted shear tests on a porous metal fiber sintered sheet (PMFSS) at different porosities. Increasing the porosity of PMFSS from 70 to $90 \%$ resulted in decreased shear strengths from 7.7 to $0.9 \mathrm{MPa}$. Zahri et al. (2020) studied the interfacial microstructure of $\mathrm{Cu}$ and $\mathrm{Cu}$ foam brazed joint. A high number of cavities were found in the brazing interface region for the highest pore density $\mathrm{Cu}$ foam leading to a low shear strength. The formation of cavities is due to the entrapped gas in the void spaces of $\mathrm{Cu}$ foam. 


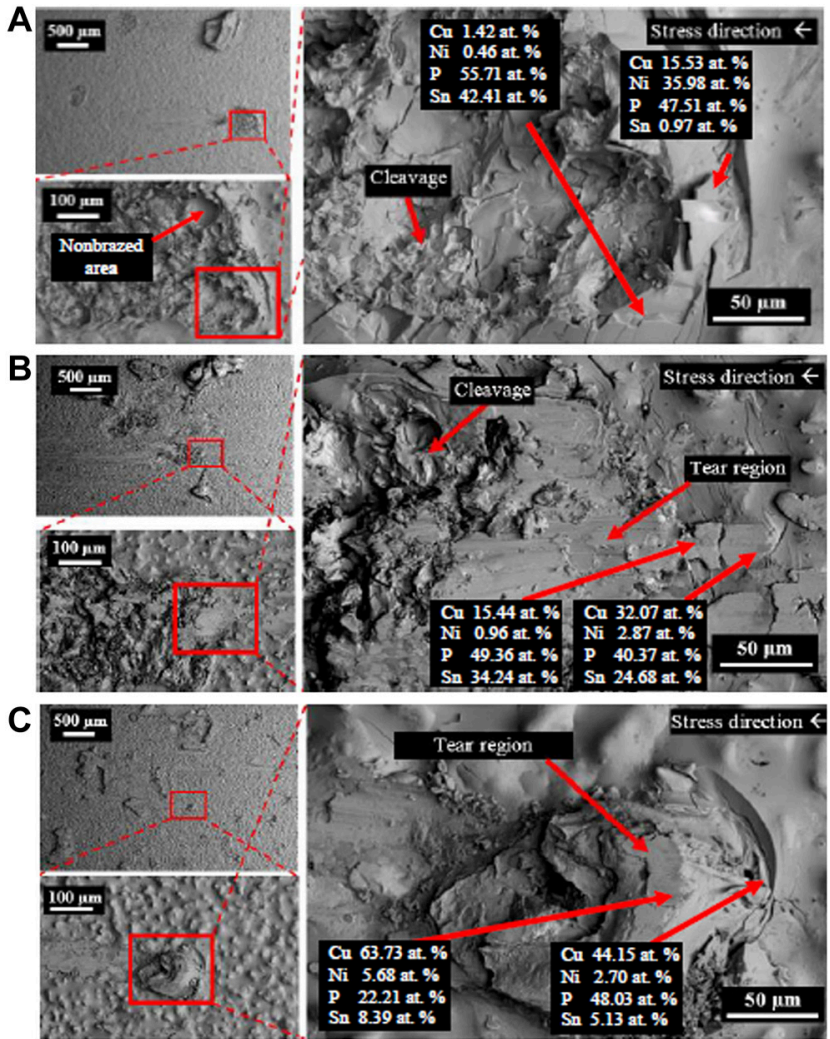

FIGURE 6 | Shear fracture of top-view Cu substrate surface from the brazed $\mathrm{Cu} / \mathrm{Cu}$ foam shear test with different $\mathrm{Cu}$ foam pore densities of (A) foam $A$, (B) foam B, and (C) foam $C$.

Moreover, the presence of copper phosphide $\left(\mathrm{Cu}_{3} \mathrm{P}\right)$ and nickel phosphide $\left(\mathrm{Ni}_{3} \mathrm{P}\right)$ brittle phases play a vital role in determining the shear strength result.

The shear stress-strain curve in Figure 5 consists of four different regions to present the shear strength behavior of $\mathrm{Cu} /$ $\mathrm{Cu}$ foam brazed joint strength. Initially, the elastic region takes place when the stress gradually increases with the increasing strain between the stress load and the brazed sample. The continual deformation presented a hardening plateau region where the stress is nearly constant with the increasing strain. Fluctuate and noise curves correspond to the solid and void spaces of the brazed joint interface between the $\mathrm{Cu}$ substrate surface and porous structures of the $\mathrm{Cu}$ foam interconnected branches. Beyond the plateau region, a larger slope and sharp increase with increasing strain is indicated by a densification region. At this region, the deformation of the brazed joint sample is subjected to compressive loading instead of shearing loading. Finally, a lower slope with nearly constant stress in the shear stress-strain curve is denoted as the shearing region. Kaya (2020) has reported a similar shear stress-strain curve for a 316L open-cell stainless steel (SS) foam. The SS foam owns high ductility and experiences a high plasticity. The plateau region and enlarged area under the shear stress-strain curve (Figure 5) indicate the $\mathrm{Cu} / \mathrm{Cu}$ foam brazed joint interface owns a high ductility property. The brazed joint of $\mathrm{Cu} / \mathrm{Cu}$ foam capable of absorbing energy before the sheared off occurs. The brazed $\mathrm{Cu}$ foam has a lower shear energy absorption capacity found from the shear stress-strain curve, compared to the compressive energy absorption capacity (compressive stress-strain curve in Figure 3).

The compressive strength and shear strength play vital roles in the brazed $\mathrm{Cu} / \mathrm{Cu}$ foam/Cu. The strength of $\mathrm{Cu}$ foam and a strong brazing joint is required properties in heat exchanger applications (Boomsma et al., 2003). The compressive strength of $\mathrm{Cu} / \mathrm{Cu}$ foam $/ \mathrm{Cu}$ is needed to accommodate strong mass fluid flow
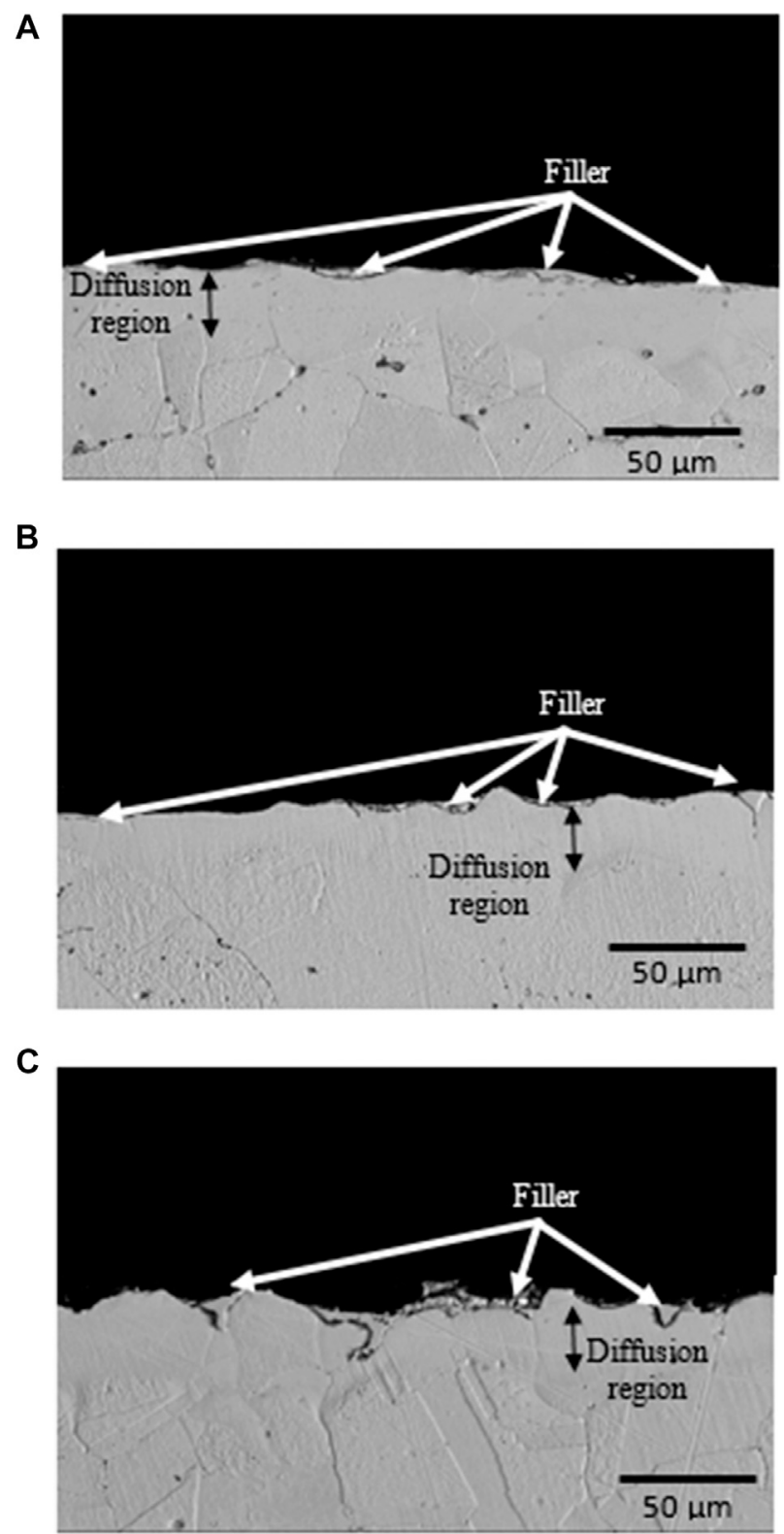

FIGURE 7 | Shear fracture of side-view Cu substrate surface from the brazed $\mathrm{Cu} / \mathrm{Cu}$ foam shear test with different $\mathrm{Cu}$ foam pore densities of (A) foam $A$, (B) foam B, and (C) foam C. 
during heat exchanger operation. While the shear strength determines the contact joining quality between substrate and the foam which affect the thermal conduction due to the thermal resistance at the joining interface (Heo et al., 2019). The highest compressive strength values obtained ranged from 10 to $12 \mathrm{MPa}$ at $720^{\circ} \mathrm{C}$. Beyond the brazing temperature of $720^{\circ} \mathrm{C}$, the metal foam branch in the brazing seam region may degrade and reduce the shear strength result. In the current work, the highest shear strength values obtained ranged from 2.8 to $3.7 \mathrm{MPa}$ at $680^{\circ} \mathrm{C}$. The current study shows that the brazing temperature at $680{ }^{\circ} \mathrm{C}$ is the most favorable to braze $\mathrm{Cu} / \mathrm{Cu}$ foam/Cu. Lower brazing temperatures minimize operational costs by saving time and energy. The American Welding Society (2006) has stated that a lower brazing temperature minimizes heating effects such as annealing, grain growth, and distortion of the substrate. Moreover, a lower brazing temperature reduces the interactions between substrate and filler metal, overcoming possible erosions of the substrate. The shear strength in the current study is adequate to withstand the pressure of fluid flow in plate-fin heat exchanger application. Shah and Sekulić (2003) have reported that the plate-fin heat exchanger is designed for a moderate operating pressure which is less than $700 \mathrm{kPa}$. Hudson Products Corporation (2007) has developed the air-cooled heat exchanger with an airflow pressure of $345-689 \mathrm{kPa}$.

The fracture behavior of $\mathrm{Cu}$ fractured surfaces from the $\mathrm{Cu} /$ $\mathrm{Cu}$ foam shear test was observed. There is a mixture of tear and cleavage regions in the BSE images of the $\mathrm{Cu}$ fractured surfaces. The enlarged area under the shear stress-strain curves of the brazed $\mathrm{Cu} / \mathrm{Cu}$ foam (Figure 5) and tear regions in BSE images (Figure 6) shows evidence of ductile behavior. BSE images show multiple crack formations were found perpendicular to the stress loading direction, then continue propagating to develop tear region, followed by brittle cleavages. Several tear regions were observed as smooth fractures probably due to shear band formation and sliding (Yang et al., 2019). There are significant differences in BSE image of the $\mathrm{Cu}$ substrate shear fracture surface of foam A, foam $B$, and foam $C$. As seen on the low magnification $(500 \mu \mathrm{m}$ scale) BSE image of Figure 6, a greater proliferation of patch marks on the $\mathrm{Cu}$ fractured surface was observed as the pore density of $\mathrm{Cu}$ foam increased (from foam A to foam $\mathrm{B}$ to foam C). The increased number of patch marks on foam $\mathrm{C}$ indicates high amounts of $\mathrm{Cu}$ foam branches were brazed with the $\mathrm{Cu}$ substrate. However, high amounts of brazed branches are not an indication of strong bond formation as shown in shear strength result. Based on previous results, low shear strength was obtained in the brazing joint of $\mathrm{Cu} / \mathrm{Cu}$ foam using $40 \mu \mathrm{m}$ filler for foam $\mathrm{C}$ (having large amounts of branches) as compared to foam A (smaller amounts of branches). This was due to the small pore sizes and hollow structures of the $\mathrm{Cu}$ foam $\mathrm{C}$ interconnected branches (Figure 1). Figure 6A shows the $\mathrm{Cu}$ substrate surface from the $\mathrm{Cu} / \mathrm{Cu}$ foam shear fracture consisting of a nonbrazed area due to the hollow structure of $\mathrm{Cu}$ foam. This nonbrazed area was surrounded by fractured $\mathrm{Cu}$ foam, indicating the foam has a hollow structure. The dark gray was found on the tear region surface which shows the filler presence and diffuses into the $\mathrm{Cu}$ foam branches. The tear region presents a ductility of $\mathrm{Cu} / \mathrm{Cu}$ foam interface before experiences a brittle fracture by cleavage formations. The EDX point analysis on the tear region (Figure 6) shows the $\mathrm{P}$ and/or $\mathrm{Ni}$ enriched. The possible phases that may present are $\mathrm{Cu}_{3} \mathrm{P}$ and $\mathrm{Ni}_{3} \mathrm{P}$ existence as reported in the previous work (Zahri et al., 2021). The past work has conducted X-ray diffraction (XRD) for the phase determination on the $\mathrm{Cu}$ fractured surface from the shear test of $\mathrm{Cu} / \mathrm{Cu}$ foam with $\mathrm{Cu}-9.0 \mathrm{Sn}$ 7.0Ni-6.0P filler. The brittle phases of $\mathrm{Cu}_{3} \mathrm{P}$ and $\mathrm{Ni}_{3} \mathrm{P}$ have appeared in the XRD pattern. Other than that, the mapping analysis was carried out on $\mathrm{Cu}$ fractured surface. There are noticeable amounts of phosphorus and nickel elements that have been accumulated in both tear and cleavage fracture. The XRD and mapping analysis in the past work support that the brittle phases of $\mathrm{Cu}_{3} \mathrm{P}$ and $\mathrm{Ni}_{3} \mathrm{P}$ have been concentrated on the fractured area. While the side-view BSE images of $\mathrm{Cu}$ substrate surface from the $\mathrm{Cu} / \mathrm{Cu}$ foam shear fracture have shown that the crack formation has propagated along the filler region, higher amounts of filler region were observed for the brazed joint interface $\mathrm{Cu} / \mathrm{Cu}$ foam $\mathrm{A}$ as compared to the brazed $\mathrm{Cu} / \mathrm{Cu}$ foam $\mathrm{B}$ and $\mathrm{Cu} / \mathrm{Cu}$ foam $\mathrm{C}$. This was due to the large pore sizes in foam A which are saturated with the filler. In contrast, $\mathrm{Cu}$ foam $\mathrm{C}$ has a higher number of branches, which are reflected in the accumulation of filler region, as observed on the $\mathrm{Cu}$ substrate surface of the $\mathrm{Cu} / \mathrm{Cu}$ foam shear fracture. The distribution of the filler region was nonhomogeneous as expected from the highly porous interconnected structure of the $\mathrm{Cu}$ foam. The highest shear strength obtained in brazed $\mathrm{Cu} / \mathrm{Cu}$ foam $\mathrm{A}$ can be attributed to the large formation of filler regions.

\section{CONCLUSION}

The joining and compressive strength of $\mathrm{Cu} / \mathrm{Cu}$ foam $/ \mathrm{Cu}$ measure the ability of foam in heat exchanger application. The large branch area with a less branch number of foam A leads to higher brazed joint strength but lower compressive strength than that of foam $\mathrm{B}$ and foam $\mathrm{C}$. The brazed $\mathrm{Cu} / \mathrm{Cu}$ foam/Cu possesses a ductile behavior that manages to resist the compressive deformation by absorbing excess energy. The $\mathrm{Cu} / \mathrm{Cu}$ foam brazed joint also capable in absorbing energy before the sheared off occur. The enlarged area under the shear stress-strain curve of brazed joint presents the $\mathrm{Cu} / \mathrm{Cu}$ foam joining owns a ductile behavior. However, a cleavage fracture (brittle behavior) was spotted on the $\mathrm{Cu}$ substrate fractured surface from the shear test of $\mathrm{Cu} / \mathrm{Cu}$ foam. The presence of $\mathrm{Ni}$ and a high concentration of $\mathrm{P}$ in the brazed joint causes the brittle behavior occurrence.

\section{DATA AVAILABILITY STATEMENT}

The raw data supporting the conclusions of this article will be made available by the authors, without undue reservation. 


\section{AUTHOR CONTRIBUTIONS}

NM, FY, H, and NS contributed to the research design and analysis of the research work. NM contributed on the data collection while IB and SK helped in providing the advice on the research work. NM wrote the first draft of the manuscript and other authors checked and revised the manuscript.

\section{REFERENCES}

Abadi, G. B., Kim, D. Y., Yoon, S. Y., and Kim, K. C. (2016). Thermal Performance of a 10-kW Phase-Change Plate Heat Exchanger with Metal Foam Filled Channels. App Therm. Eng. 99, 790. doi:10.1016/j.applthermaleng.2016.01.156

Alavi, R., Trenggono, A., Champagne, S., and Hermawan, H. (2017). Investigation on Mechanical Behavior of Biodegradable Iron Foams under Different Compression Test Conditions. Metals 7, 202. doi:10.3390/met7060202

American Welding Society (Aws) (2006). C3 on Brazing and solderingBrazing Handbook. 5th Edition. Miami, FL: American Welding Society.

Boomsma, K., Poulikakos, D., and Zwick, F. (2003). Metal Foams as Compact High Performance Heat Exchangers. Mech. Mater. 35, 1161-1176. doi:10.1016/j. mechmat.2003.02.001

Chein, R., Yang, H., Tsai, T.-H., and Lu, C. (2009). Experimental Study of Heat Sink Performance Using Copper Foams Fabricated by Electroforming. Microsyst Technol. 16, 1157-1164. doi:10.1007/s00542-009-0950-y

Chen, J., Li, X., Li, W., He, J., Li, C., Dai, S., et al. (2017). Study on the Compression Properties and Deformation Failure Mechanism of Open-Cell Copper Foam. Adv. Eng. Mater. 19, 1600861. doi:10.1002/adem.201600861

Ghosh, I. (2009). How Good Is Open-Cell Metal Foam as Heat Transfer Surface?. J. Heat Trans. 131, 1. doi:10.1115/1.3160537

Gnyloskurenko, S., Nakamura, T., Byakova, A., Podrezov, Y., Ishikawa, R., and Maeda, M. (2005). Development of Lightweight Al Alloy and Technique. Can. Metallurgical Q. 44, 7-12. doi:10.1179/00084430579440974210.1179/cmq. 2005.44.1.7

Metal foam market analysis by material (Aluminium, Nickel, Magnesium, Copper) by application (heat exchanger, energy absorbers, side impact bars), by end use and segment forecast, 2018-2025. Grand View Research. (2017). Retrieved from http://grandviewresearch.com.

Haidar, S., and Sekh, M. (2018). Effects of Production Parameters on Density and Tensile Properties of Aluminium MMC Foam. Int. J. Adv. Manage. Technol. Eng. Sci. 8, 924. Retrieved from https://www.researchgate.net/publication/ 326624037_Effects_of_Production_ Parameters_on_Density_and_Tensile Properties_of_Aluminium_MMC_Foam.

Hangai, Y., Utsunomiya, T., Kuwazuru, O., Kitahara, S., and Yoshikawa, N. (2015). Deformation and Plateau Region of Functionally Graded Aluminum Foam by Amount Combinations of Added Blowing Agent. Materials 8, 7161-7168. doi:10.3390/ma8105366

Heo, H., Kim, G., Kim, D. Y., Moon, C., Kim, K. C., Jung, K., et al. (2019). Microstructure and Mechanical Properties of Ni Foam/stainless Steel Joint Brazed Using Ni-Based Alloy. Mater. Sci. Eng. A 740-741, 63-70. doi:10.1016/j. msea.2018.10.022

Hu, H., Weng, X., Zhuang, D., Ding, G., Lai, Z., and Xu, X. (2016). Heat Transfer and Pressure Drop Characteristics of Wet Air Flow in Metal Foam under Dehumidifying Conditions. Appl. Therm. Eng. 93, 1124-1134. doi:10.1016/j. applthermaleng.2015.09.019

Hudson Products Corporation. (2007). The Basic of Air-cooled Heat Exchangers. Available at: https://files.chartindustries.com/hudson/BasicsofACHEBrochureWeb.pdf.

Jarvis, T., Voice, W., and Goodall, R. (2011). The Bonding of Nickel Foam to Ti6Al-4V Using Ti-Cu-Ni Braze Alloy. Mater. Sci. Eng. A 528, 2592-2601. doi:10. 1016/j.msea.2010.11.077

Kaya, A. C. (2020). In situ shear Behavior of Open-Cell Austenitic 316L Steel Foams. Mater. Chem. Phys. 252, 123303. doi:10.1016/j.matchemphys.2020. 123303

Kim, S-H., Heo, H-J., Yoon, T-J., and Kang, C-Y. (2016). Effect of Bonding Pressure and Bonding Time on the Tensile Properties of $\mathrm{Cu}$-Foam/Cu-Plate

\section{ACKNOWLEDGMENTS}

The authors extend their appreciation to the Deanship of Scientific Research at King Khalid University for funding this work through the research groups program under grant number RGP.2/166/42 and RU-Grant-Faculty Program, University Malaya (GPF053A2018) for the purchasing the research materials.

Diffusion Bonded Joint. Korean J. Met. Mat 54, 899. doi:10.3365/KJMM.2016 54.12 .899

Liu, P., Tan, Q., Wu, L., and He, G. (2010). Compressive and Pseudo-elastic Hysteresis Behavior of Entangled Titanium Wire Materials. Mater. Sci. Eng. A 527, 3301-3309. doi:10.1016/j.msea.2010.02.071

Liu, X.-h., Huang, H.-y., and Xie, J.-x. (2014). Effect of Strain Rate on the Compressive Deformation Behaviors of Lotus-type Porous Copper. Int. J. Miner Metall. Mater. 21, 687-695. doi:10.1007/s12613-014-0959-9

Mancin, S., Zilio, C., Diani, A., and Rosetto, L. (2012). Experimental air heat transfer and pressure drop through copper foams. Exp. Therm. Fluid Sci. 36, 224-232. doi:10.1016/j.expthermflusci.2011.09.016

Nannan, C., Yi, F., Jie, C., Bin, L., Fanyan, C., and Jingsong, Z. (2013). Vacuum Brazing Processes of Aluminum Foam. Rare Metal Mater. Eng. 42, 1118-1122. doi:10.1016/S1875-5372(13)60072-7

Nawaz, K., Bock, J., and Jacobi, A. M. (2012). Thermal-hydraulic Performance of Metal Foam Heat Exchangers [Paper Presentation 2012, July 16-19]. 14th in International Refrigeration and Air Conditioning Conference (Indiana, US: Purdue University. ). Retrieved from https://docs.lib.purdue.edu/iracc/1283/. doi:10.1615/tfec2018.tfh.020802

Ochiai, S., Nakano, S., Fukazawa, Y., Aly, M. S., Okuda, H., Kato, K., et al. (2010). Tensile Deformation and Failure Behavior of Open Cell Nickel and Copper Foams. Mater. Trans. 51, 699-706. doi:10.2320/matertrans.M2009383

Odabaee, M., and Hooman, K. (2012). Metal Foam Heat Exchangers for Heat Transfer Augmentation from a Tube Bank. Appl. Therm. Eng. 36, 456-463. doi:10.1016/j.applthermaleng.2011.10.063

Ramos, A. I. C., and Dunand, D. C. (2012). Preparation and Characterization of Directionally Freeze-Cast Copper Foams. Metals 2, 265-273. doi:10.3390/ met2030265

Ribeiro, G. B., Barbosa, J. R., and Prata, A. T. (2012). Performance of Microchannel Condensers with Metal Foams on the Air-Side: Application in Small-Scale Refrigeration Systems. App Therm. Eng. 36, 152160. doi:10.1016/j. applthermaleng.2011.12.032

Rybar, R., Beer, M., Kudelas, D., and Pandula, B. (2016). Copper Metal Foam as an Essential Construction Element of Innovative Heat Exchanger. Metalurgija 55, 489, 2016 . Retrieved from: https://hrcak.srce.hr/file/226427.

Sami, M. M., Zaharinie, T., Yusof, F., and Ariga, T. (2020). Investigation on Strength and Microstructural Evolution of Porous $\mathrm{Cu} / \mathrm{Cu}$ Brazed Joints Using Cu-Ni-Sn-P Filler. Metals 10, 416. doi:10.3390/met10030416

Saw, L. H., Ye, Y., Yew, M. C., Chong, W. T., Yew, M. K., and Ng, T. C. (2017). Computational Fluid Dynamics Simulation on Open Cell Aluminium Foams for Li-Ion Battery Cooling System. Appl. Energ. 204, 1489-1499. doi:10.1016/j. apenergy.2017.04.022

Shah, R. K., and Sekulić, D. P. (2003). Fundamentals of Heat Exchanger Design. Hoboken, New Jersey: John Wiley \& Sons. doi:10.1002/9780470172605

Shirzadi, A. A., Zhu, Y., and Bhadeshia, H. K. D. H. (2008). Joining Ceramics to Metals Using Metallic Foam. Mater. Sci. Eng. A 496, 501-506. doi:10.1016/j. msea.2008.06.007

Song, Y. F., Xiao, L. R., Zhao, X. J., Zhou, H., Zhang, W., Guo, L., et al. (2015) Fabrication, Microstructure and Shear Properties of Al Foam Sandwich. Mater. Manufacturing Process. 31, 1046-1051. doi:10.1080/10426914.2015.1037900

Srinath, M. S., Sharma, A. K., and Kumar, P. (2011). A New Approach to Joining of Bulk Copper Using Microwave Energy. Mater. Des. 32, 2685-2694. doi:10.1016/ j.matdes.2011.01.023

Sun, R., Zhu, Y., Guo, W., Peng, P., Li, L., Zhang, Y., et al. (2018). Microstructural Evolution and Thermal Stress Relaxation of Al2O3/1Cr18Ni9Ti Brazed Joints with Nickel Foam. Vacuum 148, 18-26. doi:10.1016/j.vacuum.2017.10.030

Tan, W.-C., and Chong, K.-K. (2016). Simplification of Heat Transfer Modelling for 3-D Open Cell Copper Foam by Using Single-Direction Aligned Cylinder- 
Bank Geometry. Appl. Therm. Eng. 107, 1192-1200. doi:10.1016/j. applthermaleng.2016.07.035

Tuzovskaya, I., Pacheco Benito, S., Chinthaginjala, J. K., Reed, C., Lefferts, L., and Van Der Meer, T. (2012). Heat Exchange Performance of Stainless Steel and Carbon Foams Modified with Carbon Nano Fibers. Int. J. Heat Mass Transfer 55, 5769-5776. doi:10.1016/j.ijheatmasstransfer.2012. 05.073

Ubertalli, G., Ferraris, M., and Bangash, M. K. (2017). Joining of AL-6016 to AlFoam Using Zn-Based Joining Materials. Composites A: Appl. Sci. Manufacturing 96, 122-128. doi:10.1016/j.compositesa.2017.02.019

Vesenjak, M., Hokamoto, K., Sakamoto, M., Nishi, T., Krstulović-Opara, L., and Ren, Z. (2016). Mechanical and Microstructural Analysis of Unidirectional Porous (UniPore) Copper. Mater. Des. 90, 867-880. doi:10.1016/j.matdes.2015. 11.038

Wan, Z., Liu, B., Zhou, W., Tang, Y., Hui, K. S., and Hui, K. N. (2012). Experimental Study on Shear Properties of Porous Metal Fiber Sintered Sheet. Mater. Sci. Eng. A 544, 33-37. doi:10.1016/j.msea.2012.02.070

Wang, H., and Guo, L. (2016). Experimental Investigation on Pressure Drop and Heat Transfer in Metal Foam Filled Tubes under Convective Boundary Condition. Chem. Eng. Sci. 155, 438-448. doi:10.1016/j.ces.2016.08.031

Xie, S., and Evans, J. R. G. (2004). High Porosity Copper Foam. J. Mater. Sci. 39, 5877-5880. doi:10.1023/B:JMSC.0000040107.04387.b7

Yang, G.-N., Shao, Y., and Yao, K.-F. (2019). Understanding the Fracture Behaviors of Metallic Glasses-An Overview. Appl. Sci. 9, 4277. doi:10. 3390/app9204277

Zaharinie, T., Huda, Z., Izuan, M. F., and Hamdi, M. (2015). Development of Optimum Process Parameters and a Study of the Effects of Surface Roughness on Brazing of Copper. Appl. Surf. Sci. 331, 127-131. doi:10.1016/j.apsusc.2015. 01.078

Zahri, N. A. M., Yusof, F., Ariga, T., Haseeb, A. S. M. A., Mansoor, M. A., and Sukiman, N. L. (2019). Open Cell Copper Foam Joining: Joint Strength and Interfacial Behaviour. Mat Sci. Techno 35, 2004. doi:10.1080/02670836.2019. 1661649
Zahri, N. A. M., Yusof, F., Miyashita, Y., Ariga, T., Haseeb, A. S. M. A., Jamadon, N. H., et al. (2020). Brazing of Porous Copper Foam/copper with Amorphous Cu-9.7Sn-5.7Ni-7.0P (Wt\%) Filler Metal: Interfacial Microstructure and Diffusion Behavior. Weld World 64, 209. doi:10.1007/ s40194-019-00804-2

Zahri, N. A. M., Yusof, F., Miyashita, Y., Ariga, T., Haseeb, A. S. M. A., and Sukiman, N. L. (2021). Effect of Porous Copper Pore Density on Joint Interface: Microstructure and Mechanical Analysis. J. Harbin Ins Tech.. doi:10.11916/j. ssn.1005-9113.2020056

Zhang, Y., Long, E., and Zhang, M. (2018). Experimental Study on Heat Sink with Porous Copper as Conductive Material for CPU Cooling. Mater. Today Proc. 5, 15004-15009. doi:10.1016/j.matpr.2018.04.046

Zhao, C. Y., Lu, W., and Tassou, S. A. (2006). Thermal Analysis on Metal-Foam Filled Heat Exchangers. Part II: Tube Heat Exchangers. Int. J. Heat Mass Transfer 49, 2762-2770. doi:10.1016/j.ijheatmasstransfer.2005.12.014

Zhao, C. Y. (2012). Review on Thermal Transport in High Porosity Cellular Metal Foams with Open Cells. Int. J. Heat Mass Transfer 55, 3618-3632. doi:10.1016/j. ijheatmasstransfer.2012.03.017

Zhong, Z., Zhou, J., Shen, X., and Ling, X. (2012). Study on Vacuum Brazing of Glass to Kovar ${ }^{\circledR}$ Alloy with Cu-Ni-Sn-P. Weld J. 91, 237, 2012 . Retrieved from: http://files.aws.org/wj/supplement/WJ_2012_09_s237.pdf.

Conflict of Interest: The authors declare that the research was conducted in the absence of any commercial or financial relationships that could be construed as a potential conflict of interest.

Copyright (C) 2021 Mohd Zahri, Yusof, Badruddin, Haseeb, Sukiman and Kamangar. This is an open-access article distributed under the terms of the Creative Commons Attribution License (CC BY). The use, distribution or reproduction in other forums is permitted, provided the original author(s) and the copyright owner(s) are credited and that the original publication in this journal is cited, in accordance with accepted academic practice. No use, distribution or reproduction is permitted which does not comply with these terms. 